\title{
STRES, STRESOR DAN KOPING STRES PADA MAHASISWA KEPERAWATAN DAN KEBIDANAN DI STIKES HARAPAN BANGSA PURWOKERTO
}

\author{
Martyarini Budi Setyawati ${ }^{1}$, Murniati ${ }^{2}$ \\ STIKES Harapan Bangsa Purwokerto \\ ${ }^{1)}$ martyarini.bs@gmail.com \\ ${ }^{2)}$ murniati@shb.ac.id
}

\begin{abstract}
Nursing and midwifery students during their education are often exposed to various stressors. The most common sources of stress experienced by students are assignments, exams, clinical practice workloads, and clinical/academic skills compliance. The presence of stress can affect their learning and performance. In addition, the excessive stress can be harmful to students academic performance, wellbeing, and can interfere with complex learning, psychomotor skills. The aim of this study to describe the level of stress, stressors and coping strategies of students who undergoing undergraduate nursing, nursing diploma and midwifery diploma.

This cross sectional study conducted on Institute of Health Science Harapan Bangsa Purwokerto on Juni 2016. A total of 95 students of undergraduate nursing, diploma nursing, and diploma midwifery students were taken by proportionate random sampling. Research data were collected utilizing Nursing Student Stress Scale, PhysioPsycho-Social Scale, and Simplified Coping Style Questionnaire. The data analyzed by univariate analysis and presented in frequency's distribution.

Findings of this research indicated that nurse and midwifery students experienced moderate level of stress (71,5\%) and moderate physio psycho social responses (54,7\%). Stress from clinical environment was the most common stressor that identified (34,9\%). In addition, nursing and midwifery students have an adaptive coping strategies $(88,4 \%)$.

The results indicated that stress is common in nursing and midwifery education and it may have an impact on their physio psycho social responses. Therefore, knowledge about stress level and its sources on nursing and midwifery students are important to identified the adaptive coping strategies.
\end{abstract}

Keywords: stress level, stressor, coping strategies, nursing students, midwifery students

\section{PENDAHULUAN}

Stres dalam pendidikan keperawatan diakui sebagai salah satu isu yang paling penting dalam dunia modern. Lazarus dan Folkman (2004) mendefinisikan stres psiko-sosial sebagai hubungan tertentu antara orang dan lingkungan yang dinilai oleh orang sebagai ancaman atau lebihnya sumber bahaya. Ketidakseimbangan antara tuntutan lingkungan dan sumber daya yang dipunyai individu untuk memenuhi tuntutan mereka. Jika tuntutan melebihi sumber daya, stres dapat terjadi pada individu. Stres sekunder terjadi ketika seorang individu menentukan kapasitas mereka untuk mengelola tuntutan lingkungan.

Selama pendidikan keperawatan dan kebidanan, baik diploma maupun sarjana, mahasiswa sering terkena berbagai stresor yang dapat langsung atau tidak langsung menghambat belajar dan kinerja mereka. Sifat pendidikan klinis menyajikan tantangan yang dapat menyebabkan siswa mengalami stres. Selain itu, komponen praktis dari program yang penting dalam mempersiapkan siswa untuk berkembang dan mempunyai perantenaga kesehatan profesional membuat mahasiswa lebih stres daripada program studi 
lain (Labrague, 2013)

Studi menunjukkan bahwa mahasiswa bidang kesehatan mempunyai tingkat stres yang lebih tinggi, dan rentan terhadap stres bila dibandingkan mahasiswa program lainnya. Stecker (2004) menemukan bahwa mahasiswa keperawatan mengalami stres akademik dan stres eksternal yang lebih tinggi daripada mahasiswa program studi terapi fisik, farmasi, kedokteran gigi dan kedokteran, sedangkan mahasiswa kebidanan seringkali mengalami stres pada kehidupan personal maupun profesional. Padatnya perkuliahan yang harus disertai dengan ketrampilan praktik dan berbagai kegiatan lain seperti penugasan dan kegiatan intrakulikuler dapat menimbulkan stres jika tidak diiringi dengan manajemen waktu yang baik (Ratnasari, 2013).

Beberapa penelitian menunjukkan bahwa ada banyak sumber stres selama pendidikan keperawatan dan kebidanan. Sumber yang paling umum dari stres diidentifikasi oleh mahasiswa dan fakultas yang berhubungan dengan akademisi termasuk tuntutan akademik, penugasan dan ujian, beban kerja praktik klinik yang tinggi, dan pemenuhan keseimbangan ketrampilan klinik dan akadeik (Ryan, 2008). Penelitian mengenai prevalensi stres pada mahasiswa kesehatan telah dilakukan pada beberapa universitas. Penelitian yang dilakukan terhadap 100 mahasiswa program kesehatan di Amerika Utara menunjukkan bahwa prevalensi stres pada mahasiswa adalah 38\% (Shannone, 1999). Penelitian sejenis dilakukan oleh Firth (2004) pada salah satu fakultas kesehatan di
Inggris.

Penelitian yang melibatkan 165 partisipan tersebut menunjukkan prevalensi stres pada mahasiswa adalah $31,2 \%$. Sementara itu, tiga penelitian yang dilakukan di Asia menunjukkan hasil sebagai berikut: (1) Pakistan, dengan 161 partisipan, prevalensi stres mahasiswa adalah 30,84\% (Shah, Hasan, Malik, \& Sreeramareddy, 2010), (2) Thailand, dengan 686 partisipan, prevalensi stres mahasiswa keperawatan adalah 61,4\% (Saipanish, 2003), (3) Malaysia, dengan 396 partisipan, prevalensi stres mahasiswa adalah 41,9\% (Sherina, 2004). Berdasarkan penelitian tentang tingkat stres yang dilakukan oleh Abdulghani (2008) di Saudi Arabia terhadap 494 partisipan, diketahui bahwa prevalensi stres pada mahasiswa adalah 57\% dimana $21,5 \%$ diantaranya merupakan stres ringan, $15,8 \%$ stres sedang, dan $19,6 \%$ stres berat. Penelitian sejenis di Iran yang diikuti 129 partisipan menunjukkan prevalensi stres pada mahasiswa fakultas kesehatan adalah $61,47 \%$ dimana $26,22 \%$ diantaranya merupakan stres ringan, 20,5\% stres sedang, dan $14,75 \%$ stres berat (Marjani, Gharavi, Jahanshahi, dan Vahidirad, 2008).

Sumber stres meliputi: ketakutan, lingkungan klinis yang baru diketahui, (Keck 2009), konflik antara praktek klinis yang ideal dan nyata, (Lindop, 2011), pemahaman riwayat medis, kurangnya keterampilan keperawatan dan kebidanan profesional, diagnosis dan perawatan pasien asing, menyediakan perawatan fisik, psikologis dan sosial untuk pasien, takut membuat kesalahan, memberikan obat untuk anak-anak, dan 
kematian patient (Sheu et al, 2002). Watson (2008), menemukan bahwa stres yang dialami oleh mahasiswa keperawatan dan kebidanan dalam praktek klinis meningkat dan berkembang seiring periode praktek berlangsung.

Stres memiliki efek yang merugikan tidak hanya pada kesehatan fisio-psiko-sosial individu tetapi juga menjadi secara keseluruhan kesejahteraan mahasiswa. Penelitian telah menunjukkan bahwa stres yang berlebihan dapat berbahaya bagi kinerja akademik siswa, kesejahteraan, dan bisa mengganggu belajar kompleks, psikomotor skill (Hughes, 2005). Selanjutnya, stres bisa mengakibatkan gejala merusak seperti alkoholisme dan ketergantungan obat, gangguan makan, penggunaan sembarangan zat ilegal, gangguan tidur, absensi, gangguan kesehatan mental, dan gejala psikologis bahkan bunuh diri (Timmins \& Kaliszer, 2002).

Berdasarkan uraian di atas, diketahui bahwa stres merupakan kondisi yang umumnya dialami oleh mahasiswa keperawatan dan kebidanan. Oleh karena itu, peneliti tertarik untuk meneliti tingkat stres, stressor dan koping stres pada mahasiswa Keperawatan dan Kebidanan Tinggi Ilmu Kesehatan Harapan Bangsa. Hasil yang dapat diperoleh dari penelitian ini akan memberikan informasi penting dan berguna bagi para pendidik perawat dalam mengidentifikasi kebutuhan siswa, memfasilitasi belajar mereka baik dalam akademisi dan pengaturan klinis, dan perencanaan intervensi dan strategi yang efektif untuk mengurangi stres dalam pendidikan klinis.

\section{METODOLOGI}

Penelitian ini merupakan studi deskriptif dengan pendekatan cross sectional. Penelitian ini melibatkan 95 yang dihitung dengan menggunakan rumus slovin terhadap 317 mahasiswa Prodi Keperawatan S1, Keperawatan D3 dan Kebidanan D3 yang telah melewati pembelajaran klinik. Teknik pengambilan sampel dengan menggunakan proportionate random sampling. Instrumen yang digunakan dalam penelitian ini adalah Nursing Student Stress Scale, Physio-PsychoSocial Responses dan Simplified Coping Style Questionnaire. Pengambilan data dilakukan pada bulan Juni 2016. Data yang diperoleh dianalisis menggunakan analisis univariat dan disajikan dalam bentuk distribusi frekuensi.

\section{HASIL DAN PEMBAHASAN}

Sebanyak 95 mahasiswa keperawatan dan kebidanan dilibatkan dalam penelitian ini. Berdasarkan distribusi responden, jumlah terbanyak yaitu responden dari mahasiswa Program Studi S1 Keperawatan (49\%), disusul 35\% mahasiswa Program Studi Keperawatan D3 dan 16\% mahasiswa Program Studi Kebidanan D3. Hal ini berdasarkan penghitungan rerata jumlah mahasiswa di STIKES Harapan bangsa yang dapat ditinjau dari tabel 1 tentang distribusi responden, tingkat stres, stressor, respon fisio-psiko-sosial dan mekanisme koping mahasiswa keperawatan dan kebidanan. 
Tabel 1. Distribusi Responden, Tingkat Stres, Stressor, Respon Fisio-Psiko-Sosial dan Mekanisme Koping Mahasiswa Keperawatan dan Kebidanan

\begin{tabular}{lc}
\hline \multicolumn{1}{c}{ Variabel } & $\mathrm{f}(\%)$ \\
\hline Jenis Kelamin & \\
Mahasiswa S1 Keperawatan & $28(64 \%)$ \\
Laki-Laki & $19(36 \%)$ \\
Perempuan & $7(21 \%)$ \\
Mahasiswa D3 Keperawatan & $26(79 \%)$ \\
$\quad$ Laki-Laki & \\
Perempuan & $0(0 \%)$ \\
Mahasiswa D3 Kebidanan & $15(100 \%)$ \\
Laki-Laki & \\
Perempuan & $26(27,3 \%)$ \\
Tingkat Stress & $68(71,5 \%)$ \\
Ringan & $1(1,2 \%)$ \\
Sedang & \\
Berat & $11(11,6 \%)$ \\
Sumber Stres (Stresor) & $17(17,8 \%)$ \\
Kurang Pengetahuan dan Skill & $4(4,3 \%)$ \\
Beban Tugas & $33(34,9 \%)$ \\
Merawat Pasien & $17(17,8 \%)$ \\
Lingkungan Praktik & $13(13,6 \%)$ \\
Dosen dan Instruktur Klinik (CI) & \\
Teman dan Keseharian & $27(28,4 \%)$ \\
Respon Fisio-Psiko-Sosial & $52(54,7 \%)$ \\
Baik & $16(16,9 \%)$ \\
Cukup & $84(88,4 \%)$ \\
Buruk & $11(11,6 \%)$ \\
Strategi/Mekanisme Koping & \\
Adaptif & \\
Tidak Adaptif & \\
\hline
\end{tabular}

Hasil penelitian ini menunjukkan bahwa $71,5 \%$ responden mengalami tingkat stres sedang dan hanya sebesar $1,2 \%$ responden melaporkan stres berat. Temuan ini sesuai dengan hasil yang diperoleh oleh beberapa peneliti sebelumnya. Papazisiz (2000), dalam sebuah penelitian yang dilakukan di kalangan siswa perawat Yunani mendapatkan hasil sebagian besar mengalami stress ringan. Stres dalam jumlah minimal dapat bermanfaat pada kesejahteraan seseorang terutama ketika dihadapkan dengan tantangan dan tanggung jawab. Namun perpanjangan dari stress dan atau terpapar terus menerus dengan sumber stressor dapat membahayakan bagi individu. Hasil dari penelitian ini merupakan dasar untuk menjawab tantangan yang lebih besar bagi para pendidik profesi perawat dan bidan dalam strategi perencanaan untuk mencegah terulangnya stres di kalangan mahasiswa sekaligus menjaga mereka termotivasi untuk mencapai komptensinya.

Sementara itu hasil penelitian mengenai 
sumber stres, didapatkan sumber stres utama dari responden adalah lingkungan praktik $(34,9 \%)$, diikuti sumber stres yang berasal dari beban tugas $(17,8 \%)$, dosen dan instruktur klinik $(17,8 \%)$, teman dan kebiasaan harian $(13,6 \%)$, kurang pengetahuan dan skill $(11,6 \%)$, dan sumber stres terendah adalah merawat pasien (4,3\%). Hal ini kemungkinan disebabkan kurikulum yang dikembangkan dimana mereka banyak mendapatkan paparan klinik di masa studi akademiknya. Dibandingkan dengan kurikulum keperawatan di negara lain (di Amerika Serikat siswa hanya diminta untuk menyelesaikan sekitar 1000 jam pelatihan klinis sebelum lulus sementara di Hongkong 500 jam klinis yang diperlukan, dan di negara-negara Eropa, sekolah keperawatan/ kebidanan akan memerlukan persyaratan minimum 2300 jam praktek dalam program untuk kualifikasi awal perawat). Kurikulum keperawatan yang dikembangkan STIKES Harapan Bangsa Purwokerto memiliki paling banyak jam pelatihan klinis diperlukan antara 1722-2346 jam klinis. Untuk mahasiswa S1 Keperawatan program profesi Ners, jam klinik 1900 tanpa ada jam klasikal. Selain itu, siswa perawat dan bidan juga sarat dengan proyek, laporan, makalah, kuis, dan ujian yang lebih berat dibandingkan dengan program lainnya. Stres dari kurangnya pengetahuan profesional dan keterampilan juga dilaporkan sebagai salah satu sumber utama stres dalam penelitian ini. Terlepas dari pelatihan yang kaku dan ketat baik di dalam kelas dan lahan praktik, siswa masih merasa bahwa mereka masih memiliki subyek yang harus dipelajari lebih banyak di kampus. Sehingga, mereka takut melakukan kesalahan saat melakukan keterampilan keperawatan di daerah klinis. Kategori ini juga yang paling sering dilaporkan oleh mahasiswa keperawatan seperti dilansir Nolan dan Ryan (2008) didalam penelitiannya di negara Philiphines. Menurutnya, penelitiannya juga mengungkapkan bahwa tingkat stres yang dirasakan menurun sesuai dengan tahun kehadiran. siswa perawat senior dalam tingkat disajikan lebih rendah dari stres dibandingkan dari siswa perawat junior. Hal ini mungkin disebabkan oleh fakta bahwa, karena mereka masuk ke tingkat yang lebih tinggi, mereka mampu beradaptasi dan menyesuaikan diri dengan persyaratan akademik dan klinis. Selain itu, karena mereka maju ke tingkat yang lebih tinggi dari program ini, mereka telah memperoleh penguasaan keterampilan yang cukup yang diperlukan dalam pengalaman klinis. Hasil ini mirip dengan penelitian Leodoro Jabien Labrague (2013) bahwa mahasiswa keperawatan junior menunjukkan skor kecemasan tinggi dari siswa senior. Sebaliknya, Tully melaporkan bahwa siswa tahun kedua mempunyai tingkat stres yang lebih tinggi daripada rekan-rekan tahun pertama mereka (Labrague, 2013).

Dalam penelitian ini, respon Fisio-PsikoSosial responden didapatkan sebagian besar dalam kategori cukup $(54,7 \%)$, namun terdapat $16,9 \%$ mempunyai respon FisioPsiko-Sosial yang buruk. Meskipun tingkat stres dan respon Fisio-Psiko-Sosial responden sebagian besar dalam kategori yang sedang/cukup, akan tetapi strategi koping yang dimiliki responden mayoritas adalah adaptif $(88,4 \%)$. Koping adaptif yang dimaksud yaitu 
dengan cara resolusi/planning; lebih banyak belajar, mempersiapkan mental sebelum masuk klinik, dan mengevaluasi diri terhadap mata kuliah yang dirasa menyulitkan dipilih oleh 37,2\% mahasiswa. Sebesar 31,8\%, memilih untuk berkoping positive reappraisal yakni dengan berpikiran bahwa dirinya mampu berpikir bahwa semua harus berproses. Sebagian kecil mahasiswa menggunakan koping adaptif, significant other. Sejumlah 19,4\% mahasiswa memilih untuk menceritakan pengalaman yang membuatnya stres kepada orang yang dianggapnya penting. Hal ini bisa menjadi indikasi bahwa siswa mampu mengatasi berbagai stressor yang dihadapi selama pendidikan keperawatan/kebidanan mereka. Temuan dari penelitian ini mungkin harus dibuktikan secara korelasi antara tingkat persepsi stres dan kondisi fisio-psiko-sosial yang dirasakan. Siswa yang merasa tingkat stres yang lebih tinggi lebih mungkin untuk memiliki kondisi fisio-psiko-sosial yang rendah. Hasil ini merupakan penegasan dari teori oleh Lazarus \& Folkman yang menegaskan bahwa stres dapat mempengaruhi kesehatan fisik, psikologis dan sosial masyarakat jika hasil adaptational tidak dapat dicapai.

\section{SIMPULAN DAN SARAN}

\section{a. Simpulan}

Kesimpulan dalam penelitian ini adalah sebagian besar dari responden mempunyai tingkat stress sedang (71,5\%), dengan sumber stress utama dari responden adalah lingkungan praktek dengan $34,9 \%$, lebih dari setengah responden mempunyai respon Fisio-PsikoSosial cukup $(54,7 \%)$ dan strategi koping yang dimiliki responden mayoritas adalah adaptif, hal ini ditunjukan oleh $88,4 \%$ responden.

\section{b. Saran}

Program Studi perlu melakukan peninjauan kurikulum secara berkala, mendiskusikan dengan bagian kemahasiswaan dan akademik untuk dapat memformulasikan bahan dan metode belajar yang menyenangkan. Selain itu, memberikan pemahaman dan pembekalan yang cukup bagi mahasiswa sebelum mereka masuk ke ahan praktik juga sangat penting. Mahasiswa diharapkan dapat selalu menyeimbangkan kondisi psikologis dan menggunakan strategi koping yang adaptif untuk dapat mengatasi kepadatan belajar.

\section{DAFTAR PUSTAKA}

Abdulghani, H.M., (2008). Stress and Depression Among Medical Students: A Cross Sectional Study at a Medical College in Saudi Arabia. Pak Journal Medical Science, 24 (1): 12-17

Effendi, M. (2005). Stress Akibat Kerja Yang Dihadapi Guru Sekolah Luar Biasa. Jurnal. Departemen Pendidikan Nasional Republik Indonesia.

Firth, C.J. (2004). Emotional Distress in Junior Hospital Doctors. British Medical Journal, 295 (6): 533

Gunawati, R., Hartati, S., dan Listiara, A. (2006). Hubungan Antara Efektifitas Komunikasi Mahasiswa-Dosen Pembimbing Utama Skripsi Dengan Stress Dalam Menyusun Skripsi Pada Mahasiswa Program Studi Psikologi Fakultas Kedokteran Universitas Diponegoro. Jurnal Psikologi Universitas Diponegoro, vol.3, no.2, Desember2006

Hawari, Dadang. (2001). Manajemen Stres, 
Cemas, dan Depresi. Jakarta : Fakultas Kedokteran Universitas Indonesia

Hughes BM. Study, examination, and stress: Blood pressure assessment in college students. Educational Review 2005; 57 , 2136.http://dx.doi.org/10.1080/00131 91042000274169

Lazarus, R.S, dan Folkman, S. (2004). Stress, appraisal, and coping. Springer Publishing Company.

Labrague, L.J. (2013). Stress, Stressors, and Stress Responses of Student Nurses in a Government Nursing School. Health Science Journal, vol 7 (2013), issue 4.

Lindop E. Individual stress among nurses in training: why some leave while other stay. Nurse Education Today 1991; 11 ( 2 ) : 172 179.http://dx.doi.org/10.1016/026069 17(91)90146-2

Marjani, A., Gharavi, A.M., Jahanshahi, M., Vahidirad, A., \& Alizadeh, F., (2008). Stress among Medical Students of Gourgan (South East of Caspian Sea), Iran. Kathmandu University Medical Journal, 6 (3): 421-425.

Nolan G, Ryan D. (2008). Experience of stress in psychiatric nursing students in Ireland. Nursing Standard; 22(43),3543,PMid:18655505

Ratnasari, W. (2013). Makalah Psikologi Kesehatan tentang Stres. Makalah. 111

Safari, T dan Rahardi, K. (2004). Menjadi pribadi berprestasi. Jakarta: Grasindo

Saipanish, R., (2003). Stress among Medical Students in a Thai Medical School. Medical Teach, 25 (5), 502.

Santrock, J.W., (2003). Dalam: Kristiaji, W.C. dan Saragih, S. (eds). Adolescence Perkembangan Remaja. 6th ed. Jakarta: Erlangga

Sarafino, E. P. (2008). Health Psychology, Byopsychosocial Interactions (6th ed.). New York: John Wiley \& Sons Inc.Smet, B. (1994). Psikologi Kesehatan. Jakarta: PT. Gramedia

Shah M, Hasan S, Malik S, Sreeramareddy CT. (2010). Perceived stress, sources and severity of stress among medical undergraduates in a Pakistani medical school. BMC Medical education, 10(1):2

Shannone, R. (1999). Sources of stress among college student. College student journal, 33 (2):312

Sherina. 2004. Psychological stress among undergraduate medical students. Malaysia Medical Journal, 59. Diakses. 16 April 2013. dari : http://xa.yimg.com/kq/groups/2056 1209/2125592742/name/\%EE\%80 $\%$

0Psychological $\%$ EE $\% 80 \% 81 \%$ EE $\% 80 \% 80$ Stress $\%$ EE $\% 80 \% 81$.pdf

Sheu SL, Lin HS, Hwang SL. Perceived stress and physiopsycho-social status of nursing students during their initial period of clinical practice: the effect of coping behaviors. International Journal of Nursing Studi es 2002 ; $39,165-$ 175.http://dx.doi.org/10.1016/S002 07489(01)00016-5 Stecker, T. (2004). Well being in a academic environment. Medical Education; $38, \quad 465-478$. http://dx.doi.org/10.1046/j.13652929.2004.01812.xPMId:15107080

Timmins F,Kaliszer M. Aspects of nurse education programmes that frequently cause stress to nursing students - fact - finding sample survey. Nurse Education Today 2002; 2

20311.http://dx.doi.org/10.1054/nedt .2001.0698 PMid:12027601

Watson R, Deary I, Thompson D, Li G. A study of stress and burnout in nursing students in Hong Kong: A questionnaire survey. International Journal of Nursing Studies 2008; 45(10),1534-1542.http://dx.doi.org/1 0.1016/j.ijnurstu.2007.11.003PMid:1 8241870 